DOI: $10.15290 / \mathrm{bsl} .2021 .19 .04$

Creative Commons License: CC BY-SA 4.0

https://creativecommons.org/licenses/by-sa/4.0/deed.en

\author{
Elżbieta Rybicka \\ Wydział Polonistyki \\ Uniwersytet Jagielloński \\ e-mail: elzbieta.rybicka@uj.edu.pl \\ ORCID: 0000-0002-7643-5647
}

\title{
Peryferie pokazują język. O geolingwistycznych aspektach prozy ostatniej dekady
}

\section{Poza kulturę zawstydzania}

Fenomenem szybko dostrzeżonym i docenionym w kręgu krytycznoliterackim i historycznoliterackim była w ostatniej dekadzie "proza wiejskich przestrzeni" ${ }^{1}$ autorstwa w większości młodych twórców: Andrzeja Muszyńskiego, Wioletty Grzegorzewskiej, Macieja Płazy, Jakuba Małeckiego, Weroniki Gogoli, Pawła Potoroczyna, Martyny Bundy, Liliany Hermetz, i z ostatnich, debiutujących w 2021 roku, Macieja Bobuli i Moniki Drzazgowskiej. Ich „wspólnym mianownikiem”, zauważa Agnieszka Czyżak:

okazuje się konstruowanie (lub re-konstruowanie) wiejskich przestrzeni jako sfery krystalizowania się ludzkich przeświadczeń, (prze)sądów, emocji i specyficznego rozumienia świata („,światoodczucia”) istotnych dla współczesnych zbiorowości i wspólnot symbolicznych. [...] istotna staje się przestrzeń oraz sposoby jej tekstowego rekonstruowania: pozostaje ona bowiem znakiem określonej (choć heterogenicznej) przynależności kulturowej, a także medium jednostkowych (coraz bardziej komplikowanych) relacji z tradycją oraz nośnikiem afektywnego zakotwiczenia $w$ realiach egzystencji ${ }^{2}$.

\footnotetext{
1 Określenie „proza wiejskich przestrzeni” przyjmuję za Agnieszką Czyżak, która argumentowała, że jest ono najbardziej fortunne na aktualnym etapie rozwoju kultury i wspólnotowej samoświadomości ze względu na „swoją neutralność, pojemność oraz otwarcie na przemiany zewnątrzliterackich warunków determinujących powstawanie tekstów" [A. Czyżak, Mutacje gatunkowe czy przekroczenie konwencji - wokót zagadnień prozy wiejskich przestrzeni, "Zagadnienia Rodzajów Literackich" 2019, nr 3, s. 55].

2 Tamże, s. 57.
} 
Spośród wskazanych cech interesować mnie będą przede wszystkim powiązane $\mathrm{z}$ wiejską przestrzenią emocje i światoodczucia, afektywne zakotwiczenie w konkretnych, geograficznych lokalizacjach oraz ich artykulacje językowe. By je rozpoznać, chciałabym najpierw zasygnalizować konieczny w tym przypadku kontekst - w 2011 roku Nagrodę Nike otrzymał Marian Pilot za Pióropusz i w tym czasie rozpoczyna się prowadzona w różnych obiegach medialnych, artystycznych, naukowych debata rewizyjno-rewindykacyjna skoncentrowana na ludowej historii Polski i określona już mianem zwrotu plebejskiego ${ }^{3}$. Nie jest to tylko dyskusja o genealogiach i tożsamościach, ale też o emocjach społecznych jej towarzyszących - wstydzie, upokorzeniu, gniewie - oraz o ich wyparciu. Niemniej, pomimo sygnałów oczyszczania pola, swoistej terapii zbiorowej, dyskurs publiczny przypomina obecnie pole minowe $\mathrm{z}$ eksplodującymi pociskami klasizmu, elitaryzmu, populizmu, chamofobii. Publiczna analityka społecznego wstydu przeradza się najczęściej w gesty zawstydzania, jednej bądź drugiej strony, a wraz z nią równolegle nasila się retoryka antagonizacji ${ }^{4}$ jako element gry o kapitał moralny. Kopiuje i wzmacnia ona jednak układy hierarchiczne, a wówczas łatwo ześlizgnąć się w narrację kryptohegemoniczną. Dlatego chciałam wskazać odmienny punkt widzenia, można bowiem - to opcja zaproponowana przez antropologa Tomasza Rakowskiego - szukać alternatywy dla „kultury zawstydzenia". Mechanizmy wyjaśniające genealogie oraz "defekty" polskiego społeczeństwa mają bowiem skłonność do replikowania i stygmatyzacji pochodzenia:

Choć stygmat wiejskości, migracji do nowego, wielkomiejskiego środowiska, wstyd wiejskich korzeni łączył się z olbrzymim procesem społecznym, modernizacyjną przebudową lat PRL-u, to z pewnej perspektywy widać, że odkrywanie chłopskich genealogii równa się tłumaczeniu pewnego "defektu” tkwiącego w nowo powstającym społeczeństwie. Po raz kolejny zostaje w ten sposób odsłonięte jądro wstydu polskiej tożsamości, wypełniające losy przebudowującego się intensywnie społeczeństwa ${ }^{5}$.

I właśnie ten długotrwały, wciąż podtrzymywany dyskurs „kultury zawstydzania" tego, co wiejskie, jest w przekonaniu antropologa najbardziej

3 P. W. Ryś, Zwrot plebejski we wspótczesnej polskiej humanistyce i debacie publicznej, w: Historia. Interpretacja. Reprezentacja, t. 3, red. L. Mokrzecki, M. Brodnicki, J. Taraszkiewicz, Gdańsk 2015, s. 307-317.

4 Celnie na te problemy w nowej, ludowej historiografii zwracają uwagę M. Gospodarczyk, Ł. Kożuchowski, Nowa ludowa historia: charakterystyka i społeczno-polityczne korzenie wspótczesnych narracji o historii chtopów polskich, "Studia Socjologiczne” 2021, nr 2, s. 177-198.

5 T. Rakowski, Sztuka w przestrzeniach wiejskich i eksperymenty etnograficzne. Pożegnanie kultury zawstydzenia: jednoczasowość, zwrot ku sobie, proto-socjologia, „Teksty Drugie” 2016, nr 4, s. 66-67. 
brzemiennym $\mathrm{w}$ skutki symptomem wewnętrznego podporządkowania ${ }^{6}$. Proponowanym przez niego rozwiązaniem może być „aktualna dekolonizacja", alternatywny wobec dominacji historii, przeszłości, genealogii, sposób kontaktu z tym, co tu i teraz, a w konsekwencji otwarcie na teraźniejsze aktywności, możliwość współkształtowania interpretacji i wiedzy przez obie strony relacji społecznej. W takiej ramie możliwe jest także uchylenie bądź zneutralizowanie równie obciążającej kategorii mentalności rozumianej jako trwała dyspozycja, nieusuwalny stygmat. Rakowski przeciwstawia jej przekonanie o zdolności do bycia w ruchu, jednostki jako „aktora zawsze zdolnego i uprawnionego do przekraczania zbiorowo tworzonych dróg działania (czy dróg rozumienia)" 7 . Uznanie wewnętrznej liminalności i podstawowego prawa osoby do bycia "kimś innym" jest więc warunkiem wstępnym wyjścia poza kulturę zawstydzenia.

Argumentacja Rakowskiego wynika z rozpoznania, że wstyd w świecie społecznym i sferze publicznej ostatniej dekady nie tylko został unieruchomiony, ale też unieruchamia, stabilizuje polaryzację prowincja - centrum, wieś - miasto, blokuje przepływy i transfery oraz możliwość samostanowienia. Warto zatem zadać pytanie, czy i jakie scenariusze przekraczania kultury zawstydzenia i zawstydzania uruchamia literatura. Pytanie wynika z faktu, że wiele powieści ostatniej dekady to albo sagi rodzinne z historią tak zwanego awansu, przemieszczenia społecznego i geograficznego w tle, albo narracje, które wspominane przez Rakowskiego ,jądro wstydu polskiej tożsamości" przynajmniej próbują wydobyć z obszaru wypartych emocji.

\section{„Rozróba w polszczyźnie”}

W jaki sposób literatura wychodzi poza „kulturę zawstydzenia”? Podstawowym tropem wydaje się podążanie śladem języka, głosu, dykcji, idiomu, akcentu, tej materii literackiej zatem, która pozostaje najbardziej wrażliwa na społeczne i geograficzne nacechowania. W literackich relacjach centro-peryferyjnych warto bowiem dostrzec kwestię redystrybucji słowa - mieszania i cyrkulacji języków, wielojęzyczności, polifonizacji. Języków rozumianych jako „peryferyjne obszary mowy" ${ }^{8}$, uwarunkowane geograficznie, społecznie,

\footnotetext{
6 Tamże, s. 76.

7 Tamże, s. 83.

8 Zob. E. Rewers, Wartościowanie peryferyjnych obszarów mowy w "Czarnej poezji" Andrzeja Bursy, „Pamiętnik Literacki” 1994, nr 2, s. 138-140.
} 
kulturowo praktyki mówienia. Ostatnia dekada przyniosła znaczące ożywienie i niekiedy radykalne rozwiązania w tej kwestii - tak jakby proza literacka stała się symptomem lub zapowiedzią przeobrażeń społecznej świadomości językowej (a równocześnie wehikułem tej świadomości). W tym polu sytuuje się gwara siedlikowska Mariana Pilota, spleciona z idiomem Gombrowiczowskim w Pióropuszu; mowa pa prostu, pierwszy język bohaterów Sońki Ignacego Karpowicza; śląski, niemiecki, wasserpolski w Drachu Szczepana Twardocha; gwara środkowomałopolska w Skoruniu Macieja Płazy; śląszczyzna w powieści Od jednego Lucypera Anny Dziewit-Meller; chachłacki z pogranicza polsko-ukraińskiego na Podkarpaciu i przedziwna mieszanka francusko-alzacko-polska bohaterek Rozrzuconych Liliany Hermetz; język kaszubski w debiutanckiej powieści Szalej Moniki Drzazgowskiej. Są to, warto zauważyć, języki peryferyjności w zwielokrotnionej postaci - nie tylko geograficznej, regionalnej, etnicznej, ale też klasowej, dlatego najczęściej funkcjonują jako oznaki dystynkcji społecznej. To wartościujące nacechowanie oraz splot emocji i wernakularnego języka najcelniej chyba uzmysławia Anna Dziewit-Meller w narracyjnym komentarzu:

przemawiała ciotka, artykułując wyraźnie każde słowo pełne na siłę podniesionych pochyłych $z$ natury ",o $\mathrm{o}^{\prime \prime} \mathrm{i}, \mathrm{u}$. Od dawna aspirowała do porzucenia znienawidzonej przez siebie ślōnskij godki na rzecz literackiej polszczyzny i akcentu prosto $\mathrm{z}$ telewizji, ale ta godka pierońska, tyn podciep jynzykowy, trzymała się jej jak rzep psiego ogona i nie chciała puścić, ponieważ tkwiła - jak zawsze się ciotce wydawało - w prostackim akcencie. Słychać było aż za dobrze ten jej potężny wysiłek, gdy dźwigała pochyłe samogłoski w każdej minucie swojego życia, głównie po to, by lepiej wypaść w oczach rozmówców. Brzmieć bardziej nowocześnie, zamożnie, inteligentnie, światowo. $W$ każdym razie - nie jak Ślązaczka ${ }^{9}$.

Kwestia wielojęzyczności i hybrydyzacji językowej w prozie ostatniej dekady była już zauważana i podejmowana, do cennych ustaleń Ewy Sławkowej, Renaty Makarskiej czy Karoliny Pospiszil będę się jeszcze odwoływać, na początek chciałabym jednak przywołać szkic Mariana Pilota Tu Babel-Centralna, pochodzący z tomu esejów Matecznik opublikowanego po raz pierwszy w 1988 roku i wznowionego w 2012. Pisarz konfrontuje w nim biblijną opowieść o wieży Babel z językową specyfiką Siedlikowa, swej rodzinnej okolicy. Punktem wyjścia jest rozpoznanie wielojęzyczności tego obszaru stykowego, na którym mieszają się gwary wielkopolskie, małopolskie i śląskie. Biblijną

9 A. Dziewit-Meller, Od jednego Lucypera, Kraków 2020, s. 26. 
przypowieść czyta natomiast Pilot „pogańskim okiem” 10, wbrew normatywnym wykładniom, jako wyjście poza fundamentalizm jednego języka, jednej mowy. W obu przypadkach proponuje zadziorną reinterpretację - dla przypowieści pochwałę pomnożenia języków, a dla okolic Siedlikowa ustanawia nowe centrum polszczyzny:

Różne szkoły dialektologiczne od dziesiątków lat toczą spór o to, gdzie dokładnie ów punkt [zbiegu granic obszarów gwarowych] należy umieścić. [...] Ustalić jest trudno. Sęk bowiem w tym, że wszyscy nasi, Krajcoki, Człeki, zarówno jak Gwiździele swobodnie mówią wszystkimi tymi trzema polskimi językami. I prawie nie sposób rozpoznać, kto bardziej ślązaczy, kto zaciąga z częstochowska, a kto znowu pyrczy bardziej niż inni: różnie bywa. Trudno się rozeznać komu bardzo nawet uczonemu, jako że potrójny nurt polskiej mowy gna tu bardziej wartko niż gdzie indziej, kłębią się wzburzone jej wody, każdego dnia też jedne słowa opadają na dno, użyźniając łożysko, inne oszlifowane właśnie, odrywają się od podłoża; słowa rodzą się tu dosłownie na kamieniu, jako że i każdy kamień jest nazwany, stan pomieszania języków jest stały, tak być musi, tak trwać tu musi, bo tu przecież właśnie jest centrum polszczyzny ${ }^{11}$.

W wykładni pisarza źródłowym (jednocześnie geolingwistycznym i symbolicznym) obszarem polszczyzny staje się siedlikowska Babel, stan pomieszania języków, przestrzeń przepływów i transferów, tworzona przez mikstatników ${ }^{12}$, nosicieli słów. Przekorny gest Pilota ma w sobie coś z profanacji narodowego (i klasowego) imaginarium symbolicznego - to już nie szlacheckie Soplicowo, ale wielkopolski i chłopski Siedlików, miejsce na peryferiach, staje się "centrum polszczyzny". Co więcej, to centrum, stan pomieszania języków, jest reinterpretowany nie jako przestrzeń poróżnienia, ale uwolnienia. Tym bowiem, co wybrzmiewa najmocniej, także $w$ innych esejach pochodzących z Matecznika, jest antyfundamentalizm pisarza i pochwała wolności słowa jako alternatywy wobec jednojęzyczności.

Szkice z Matecznika zapowiadają też późniejszą powieść. Pióropusz Pilota jest wyjątkowo pokrętną narracją o transgresyjnej trajektorii biograficznej ${ }^{13}$,

10 „A gdyby tak odczytać biblijną przypowieść, odsunąwszy wpierw pojęcie grzechu, winy, kary... gdyby więc podjąć wysiłek przeczytania babelskiej historii pogańskim okiem?" [M. Pilot, Tu Babel-Centralna, w: tegoż, Nowy matecznik, Kraków 2012, s. 197].

11 Tamże, s. 199-200.

12 Mikstat to miasto $\mathrm{w}$ wielkopolskim mateczniku Pilota, pisarz traktuje jednak toponim jako trop toponomastyczny, by wydobyć jego polisemię. Zob. M. Pilot, Tu Babel-Centralna, s. 201.

13 Termin transgresyjna trajektoria biograficzna wydaje się bardziej adekwatny w przypadku powieści Pilota niż „awans społeczny”, ponieważ wychodzi poza porządek hierarchicznej drabiny społecznej. Zob. M. Grochalska, Transgresyjne trajektorie. Zmiana statusu społecznego w perspektywie biograficznej, Kraków 2011. 
to opowieść o zawstydzaniu słowem i przekraczaniu kultury zawstydzenia za sprawą anarchizmu żywiołu językowego, a zarazem o cyrkulacji i wzajemnym zapętleniu wstydu i bezwstydu, pychy i samoponiżenia. Najważniejszą jednak kwestią jest lingwistyczna babeliada, którą proponuje pisarz język powieści miesza bowiem gwarę, a zatem, według definicji Stanisława Gajdy, „ujęzykowione ujęcie rodzimej przestrzeni” 14, w tym przypadku często (choć nie wyłącznie) swojego Siedlikowa (dodam jeszcze, że Pilot jest autorem Stownika dawnej gwary Siedlikowa ${ }^{15}$ ) oraz rejestry literackie, m.in. styl gombrowiczowski ${ }^{16}$. Pomiędzy tymi dwoma idiomami - siedlikowskim, wernakularnym, peryferyjnym oraz centralnym, literackim - wyraźnie uchwytny jest rezonans, oba, choć zróżnicowane, nie tyle kontrastują, ile współpracują ze sobą, wzmacniając efekt interferencji, w obu też język staje się narzędziem ekscesu i transgresji. Wynika to z faktu, że kluczową tradycją, którą aktywizuje w powieści Pilot, jest literatura sowizdrzalska ${ }^{17}$.

Warto bowiem przypomnieć, że obok tradycji sarmackiej, szlacheckiej, pańskiej i tradycji chłopskiej (w wariancie lamentu lub pieśni buntu) istniała jeszcze jedna - mówiąc umownie, sowizdrzalska, o "zmąconym" rodowodzie, sytuująca się jednak po stronie plebejskiej ${ }^{18}$. Powody, dla których Pilot sięga po tę tradycję wydają się dość oczywiste - już jej odkrywca Aleksander Brückner zwrócił uwagę na alternatywny (i komplementarny) wobec kultury szlacheckiej w XVII wieku charakter literatury sowizdrzalskiej:

[szlachecka] prawi o rzeczypospolitej, hetmanach, walkach; sowizdrzali o rzycipospolitej (domowej), o blujmistrach i hutmanach, o utarczkach z Żydami i ,jaratykami", o dzbanie i o kartach, o kmoszkach i przekupkach, o drajhulcu (szubienicy) i łotrze, a najczęściej o żaku i jego Zośce. Niby odwrotna strona medalu ${ }^{19}$.

O wspólnocie decyduje więc przede wszystkim gest śmiechu, wywrotowej prowokacji i profanacji, ale też znamienna dla obu „złodziej-

\footnotetext{
14 S. Gajda, Gwara a język literacki, w: Amor verborum nos unit. Studia poświęcone pamięci Profesora Stawomira Gali, red. P. Stalmaszczyk, I. Jaros, Łódź 2015, s. 80.

15 M. Pilot, Ssapy, szkudły, świętojanki. Stownik dawnej gwary Siedlikowa, Warszawa 2011.

16 Szeroko o stylistycznym wymiarze powieści pisze: E. Sławkowa, Pióropusz Mariana Pilota: kolekcja stylów i archiwum pamięci kultury, „Stylistyka” 2013, t. 22, s. 309-324.

17 Na sowizdrzalski rys Ferdydurke wskazał Stanisław Grzeszczuk. Zob. S. Grzeszczuk, Błazeńskie zwierciadło. Rzecz o humorystyce sowizdrzalskiej XVI i XVII wieku, Kraków 1994, s. 9-17.

18 Tamże.

19 A. Brückner, Cechy literatury szlacheckiej i miejskiej wieku XVII, w: Ksiegga pamiątkowa ku czci Bolesława Orzechowicza, t. 1., Lwów 1916, s. 167. Cyt. za: S. Grzeszczuk, Błazeńskie zwierciadło, s. 67.
} 
ska" 20 strategia twórcza (przetwarzanie, cytowanie, parafrazowanie), wędrowne motywy (krainy „pieczonych gołąbków”, „mlekiem i miodem płynącej", której pogłosem jest w Pióropuszu ironiczna wizja kołchozu, gdzie „każdy kraść może, a choćby nie wiedzieć jaki był łapczywy, całego bogactwa nie rozkradnie!" ${ }^{21}$ ). I wreszcie eksperymentalny stosunek do języka ${ }^{22}$, żarty onomastyczne, neologizmy, przedrzeźnianie stylów i rejestrów, obscena i wulgaryzmy.

Idiom sowizdrzalski w Pióropuszu nie jest oczywiście tylko grą językową, nawiązanie do tej tradycji pełni o wiele ważniejsze funkcje, przede wszystkim pozwala uciec od samowiktymizacji, ugrzęźnięcia w pozycji ofiary, zasklepionej w poczuciu krzywdy społecznej, klasowej, historycznej. Pilot jest świadom, że ta pozycja w gruncie rzeczy zdominowała autorefleksję chłopską; w Chłopii, jednym ze szkiców z Matecznika, pytał:

Dlaczego dominujący okazał się - modnie by się powiedziało: etos, może wystarczy rzec: wzorzec chłopskości cierpiącej i cierpiętniczej, prosiebnej, pognębionej i zapamiętującej się $w$ tym pognębieniu? Przez dwór spętanej i przez dwór opętanej, zahipnotyzowanej - dwór, będący jedynym punktem odniesienia, nadziei, tęsknot - nie zaś - sprzeciwu, buntu? Dwór, ze swojej strony też, jak to zauważył Gombrowicz, ogarnięty „kompleksem parobka”? Zamiast przeciwstawiać się ciemięstwu - chłop gardził własnym losem, cierpliwie go jednocześnie znosząc. Ta chłopskość upańszczona, bezwładna... ${ }^{23}$

W dalszych fragmentach tego arcyważnego z dzisiejszej perspektywy eseju wskazywał na przeoczaną często różnicę geograficzną ${ }^{24}$ oraz historyczne osobliwości włościańskiej Wielkopolski, większy udział ludzi „luź-

20 Rybałci, pisze Grzeszczuk, „nie mieli wcale skrupułów, by okradać się wzajemnie i czerpać z najrozmaitszych źródeł, do dziś nieraz nie rozpoznanych" [S. Grzeszczuk, Błazeńskie zwierciadło, s. 359]. Warto jeszcze odnotować, że literatura sowizdrzalska nie tylko "kradła”, ale i sama - jak wynika ze wspomnień Stanisława Pigonia - podlegała "kradzieży”, to znaczy była przechwytywana przez chłopskich gawędziarzy: „Tak na przykład poznałem po raz pierwszy zabawne przygody i psoty Janka Sowiźrzała, które naturalnie opowiadający żartowniś podawał za swoje dowcipne wymysły. Dopiero z czasem miałem się przekonać, że je znalazł w straganowym druku" [S. Pigoń, Z Komborni w świat. Wspomnienia młodości, Warszawa 1983, s. 83].

21 M. Pilot, Pióropusz, Kraków 2010, s. 178. Dalsze cytaty lokalizuję w tekście głównym.

22 Zob. T. Banaś-Korniak, Ambiwalencja znaczeń: o językowych eksperymentach sowizdrzatów, w: taż, Pomiędzy tragicznościa a groteską. Studium z literatury i kultury polskiej schytku renesansu i wstępnej fazy baroku, Katowice 2007, s. 210-221.

23 M. Pilot, Nowy matecznik, s. 34.

24 Zróżnicowanie regionalne to jedno ze znamiennych przeoczeń w Ludowej historii Polski Adama Leszczyńskiego. Zwrócił na nie uwagę Cezary Obracht-Prondzyński. Zob. C. Obracht-Prondzyński, Ludowa historia Polski - ksiązka ważna i zasługująca na krytycznq lekture, „Kultura i Społeczeństwo" 2020, nr 4, s. 207-216. 
nych", uciekinierów z pańszczyzny, mniej odczuwalną obecność dworu jako punktu odniesienia oraz na wyraźną świadomość sukcesu powstania wielkopolskiego wśród jego chłopskich uczestników. Wytworzyły one odmienną, pozbawioną uległości samoświadomość regionalną i społeczną, dlatego też aktywizacja idiomu sowizdrzalskiego przez Pilota wchodzi w rezonans z wolnościowymi tradycjami regionu.

Tradycja sowizdrzalska pozwala też wymknąć się tonacji elegijnej, która dominuje w dyskusji nad wiejską prozą od czasu publikacji Kresu kultury chłopskiej Wiesława Myśliwskiego ${ }^{25}$, często przywoływanego w funkcji autorytetu, a która w narracjach wiejskich dostrzega najczęściej scenariusze żałobne ${ }^{26}$. Pozwala wreszcie uciec od idealizacji wsi, chroniąc tym samym zarówno przed nostalgią, jak i samonobilitującym pryncypializmem, przekonaniem mocno wybrzmiewającym na przykład u Myśliwskiego, który w przywoływanym już szkicu zauważał: „w dużej mierze to dzięki chłopom Polska przetrwała. Dzięki ich przywiązaniu do ziemi, do języka, do wiary. Na tych trzech bowiem fundamentach zasadzało się chłopskie trwanie tu i zawsze, z dziada pradziada" ${ }^{27}$. Rewindykacja wypartej tradycji chłopskiej sprawia, że przybiera ona kształt nad wyraz mocny, a nobilitując kulturę chłopską Myśliwski jednocześnie proponuje jej bardzo konserwatywne ujęcie. Inaczej Pilot, szuka w tradycji chłopskiej czy plebejskiej raczej tego, co ów pryncypialny ton (i wszelkie fundamentalizmy) rozmywa.

I kolejna rzecz - splot dwu idiomów, sowizdrzalskiego i Gombrowiczowskiego ("Co moje, nie moje, podobnież Kradzione” ${ }^{28}$ ), pozwala oddalić problem autentyzmu, czystego, pozbawionego obcych wpływów języka i czystej, autentycznej kultury chłopskiej. Bohater powieści kradnie słowa, niczym jego ojciec:

ojciec z dawien dawna uprawiał wysoce wyrafinowane, wielkopańskie złodziejstwo w tej tak ekskluzywnej i trudnej do umiejscowienia dziedzinie, jaką jest królestwo mowy [...] plotly się one ojcu w przedziwne korony i wieńce, umajone porwanymi w kościele łacińskimi słowami, gdzieś na Śląsku posłyszanymi hanyskami, ba, podwędzonymi zabugorcom słodyczkami i milutkami [s. 302, 304].

25 W. Myśliwski, Kres kultury chtopskiej, Warszawa 2003.

${ }_{26}$ Zob. J. Franczak, Śmierć kultury chłopskiej. Scenariusze żałobne Edwarda Redlińskiego, w: tegoż, Maszyna do myślenia. Studia o nowoczesnej literaturze i filozofii, Kraków 2019, s. 125-142; P. Czapliński, Śmierć, śmierć, inne życie. Wieś w literaturze polskiej, „Teksty Drugie” 2017, nr 6, s. 13-34.

27 Myśliwski, Kres kultury chłopskiej, s. 13.

28 W. Gombrowicz, Trans-Atlantyk, Kraków 1988, s. 39. 
Problem, wbrew pozorom, jest ważny, ponieważ kwestia "autentyzmu” ciągle nawiedza dyskurs wokół kultury wsi, niemniej Pilot, podobnie jak jego pisarska generacja (i jak Gombrowicz), dostrzega, że „czysta kultura wiejska - komentuje Jerzy Franczak - to fantazmat" 29.

Obok funkcji krytyczno-emancypacyjnych idiomu sowizdrzalskiego Pilot aktywizuje także w analogicznej roli gwarę siedlikowską („umorusaną w śląskościach i czeskościach" ${ }^{30}$ ), która ustanawia alternatywę wobec oficjalnej normy językowej i jest narzędziem „rozróby w polszczyźnie” ${ }^{31}$ :

Nigdy nie mogłem się pogodzić z obowiązującą od XIX wieku jeszcze oficjalną polszczyzną literacką szlachecko-inteligenckiej proweniencji. Zresztą nigdy się nie starałem nawet... Język literatury coraz bardziej oddala się od języka codzienności, od żywej mowy. Były różne bunty, ale ciągle ten sztywny kanon obowiązuje, ciągle wszystko, co nowe, jest do niego przymierzane. [...] Głosił Pankowski hasło „rozróby w polszczyźnie” - jest to hasło dziś bardziej aktualne niż kiedykolwiek, nasz język staje się bowiem coraz bardziej niemrawy i niedołężny. Rzec można, podkulił ogon, pokornie przyjmuje wszystko, co mu angielski przyniesie; więcej nawet - cofa się z obszarów niegdyś przez siebie zajmowanych ${ }^{32}$.

Na marginesie deklaracji Pilota można jeszcze dodać dwie uwagi. Po pierwsze, polszczyzna literacka uwarunkowana jest nie tylko genealogią klasową, ale i zróżnicowaniem geograficznym. Mirosława Sagan-Bielawa, rekonstruując społeczną świadomość językową w okresie międzywojennym, a zatem w czasie wprowadzania ogólnopolskiej normy, zwraca uwagę, że kryterium poprawnościowym stało się wówczas „ucho warszawiaka":

Stereotyp, że dialekt kulturalny Warszawy równa się językowi ogólnopolskiemu, budował dwa rodzaje przekonań: 1) o istnieniu wzorca warszawskiego, do którego trzeba się bezwzględnie dostosować; 2) o tym, że pojęcie prowincjonalizmu nie dotyczy Warszawy, a formy prowincjonalne (regionalne), czyli takie, które mają ograniczony zasięg terytorialny, znajdują się poza dzielnicą warszawską ${ }^{33}$.

29 J. Franczak, Śmierć kultury chłopskiej, s. 127.

30 M. Pilot, J. Koźbiel, Zbici z pantałyku, „Więź" 2012, nr 5-6, s. 128.

31 Zob. P. Marecki, „Nam wieczna w polszczyźnie rozróba”. Marian Pankowski mówi, Kraków 2011.

32 M. Pilot, J. Koźbiel, Zbici z pantałyku, s. 128-129.

33 M. Sagan-Bielawa, Dziedzictwo pozaborowe: społeczna świadomość językowa Polaków w Drugiej Rzeczypospolitej, Kraków 2014, s. 111. Zob. też E. Woźniak, Polityka językowa państwa polskiego w okresie międzywojennym, "Socjolingwistyka" 2015, nr 29, s. 7-20. 
W trakcie tego fascynującego dzisiaj procesu normatywizacji polszczyzny toczyły się liczne spory - o zachwaszczanie języka polskiego, skażenie prowincjonalizmami, mową gminną, o skłonności separatystyczne lub prawo do języków mniejszych i regionalnych (Jan Stanisław Bystroń i Kazimierz Nitsch upominali się na przykład o uszanowanie prawa do odrębności terytorialnych) ${ }^{34}$.

Po drugie, „żywa mowa”, o której wspomina Pilot, przywołuje oczywiście echem założenia $\mathrm{z}$ okresu rozwoju nurtu chłopskiego $\mathrm{w}$ literaturze i programu Henryka Berezy ${ }^{35}$, a gdyby sięgnąć dalej, to także wcześniejsze lub równoległe fale otwierania prozy na oralność. Tyle że pisarz przywraca klasową ramę języka, której w Związkach naturalnych zabrakło: „Bereza - zauważa Andrzej Skrendo - walkę klasową zamienił ostatecznie w starcie dwóch abstrakcyjnych bytów, języka pierwszego i języków wtórnych [...]. Język pierwszy to inne imię chłopskiej genealogii kulturalnej, ale imię, w którym roztapia się sama ta genealogia" ${ }^{36}$. Niemniej, trzeba jeszcze koniecznie dodać, Marian Pilot jest literackim harcownikiem i babelistą, więc w prosty schemat walki klasowej i emancypacji żadną miarą wpisać się nie da, czego najlepszym dowodem są jego lingwistyczne harce.

Pilot aktywizuje gwarę na wiele sposobów. Z jednej strony traktuje ją jako narzędzie „rozróby w polszczyźnie”, pobudzania niemrawego języka oficjalnego żywą, pełną wigoru mową, dosadną, gorącą, soczystą. Niekiedy też sięgającą bardzo głęboko w archaiczne złoża pamięci językowej, nie tylko regionalnej - matczyne zawołanie „uskróm się!” ${ }^{37}$ [s. 150] to przecież leksykalny relikt z polszczyzny Jana Kochanowskiego i Szymona Szymonowica. $Z$ drugiej strony kapitalnie pokazuje też w powieści oddolną moc inwencyjnego tworzenia słów, czerpie bowiem nie tylko z zasobu języka zastanego, ale również nieustannie produkuje nowe. $Z$ badań językoznawczych wynika, że w Pióropuszu blisko 40 procent leksemów pejoratywnych odnoszących się do osób to neologizmy ${ }^{38}$. Wbrew sugestiom narracyjnym neologizmem nie

34 Zob. M. Sagan-Bielawa, Język jako element świadomości społecznej (na przykładzie Polski po 1918 roku), „LingVaria” 2017, nr 2, s. 218-219.

35 H. Bereza, Związi naturalne. Szkice literackie, Warszawa 1978, s. 31-35.

36 A. Skrendo, "Nocny złodziej jabłek” - Henryk Bereza i nurt chłopski w prozie polskiej, "Teksty Drugie" 2017, nr 6, s. 50.

37 "Uskróm się, tego słowa z siedlikowskiej i marydolskiej mowy nie przejęła książkowa polszczyzna, choć żadnym innym wyrażeniem nie umie oddać żaru, mocy ani istoty głębokich treści tego matczynego zawołania" [s. 150]. Warto pamiętać, że narracyjne komentarze prowadzą niekiedy na manowce.

38 M. Sabała, Wymoczek vs. Niczciwiara. Pejoratywne określenia człowieka w Pióropuszu Mariana Pilota, „StruNa - Biuletyn Młodych Naukowców” 2012, nr 1, s. 94. 
musi być natomiast „niczciwiara” ${ }^{99}$ : „Takiej niczciwiary (ten w błysku natchnienia przez matkę ukuty olśniewająco celny neologizm oznaczał precyzyjnie osobę pozbawioną czci i wiary)” [s. 148]. W przypadku "niczciwiary” bardziej istotny niż autentyczność wydaje się jednak fakt, że językowa innowacyjność, "płodność słowotwórcza" 40 i sprawczość zostały przypisane kobiecie, pozbawionej wykształcenia chłopce.

Językowy witalizm współgra jednocześnie z myśleniem o mowie chłopskiej jako przestrzeni wolności, często deklarowanym przez Pilota: „Artur Sandauer powiedział kiedyś, że chłop, który znosić musiał wszelakie niewole, w jednej dziedzinie cieszył się wolnością większą niż wszyscy inni: w języku, w słowie" ${ }^{41}$. Tę wolność słowa najmocniej i najbardziej ekspresywnie wydobywają wulgaryzmy - Pilot bowiem genialnie pomnożył zasoby leksykalne polszczyzny w tej dziedzinie. Ich rola nie ogranicza się oczywiście do artykulacji emocji - to równocześnie, zgodnie z klasycznymi definicjami, akty transgresji, przekraczanie tabu językowego ${ }^{42}$. Niemniej także coś więcej. Serie kotłujących się inwektyw i wulgaryzmów są precyzyjnie umotywowane sytuacją - pojawiają się w wielkiej tyradzie matki przeciw Krajonkom, w pyskówce młodych bohaterów podczas sceny w młynie oraz w samoponiżającym akcie deprecjacji narratora. I wszystkie są popisami inwencji językowej, nie tyle samozwrotnej, ile łączącej kreatywność, anarchizującą żywiołowość i obsceniczność, czasem nawet akty profanacji. Pilot nie nobilituje przy tym języka vulgus, ale hiperbolizując i spiętrzając wulgaryzmy, przeprowadza je na stronę ludyczności. A przy okazji inspiruje do pytań o rolę wulgaryzmów $\mathrm{w}$ oralnej kulturze wsi, o ludową funkcjonalizację złorzeczenia ${ }^{43}$. Choć też - za sprawą licznych w tej grupie neologizmów - o ich materię, zasady tworzenia, innowacyjność słowotwórczą czy mechanizmy lub logikę "słoworodów ludowych".

\footnotetext{
39 Tamże, s. 91.

40 To określenie Katarzyny Chmielewskiej. Zob. K. Chmielewska, Wynalazek tożsamości, w: Gry o tożsamość w czasach wielkiej zmiany, red. A. Werner, T. Żukowski, Warszawa 2013, s. 216.

41 M. Pilot, J. Koźbiel, Zbici z pantałyku, s. 134. Por. też: W. Myśliwski, Kres kultury chłopskiej, s. $24-25$.

42 Według klasycznej już definicji Macieja Grochowskiego wulgaryzm to ,jednostka leksykalna, za pomocą której mówiący ujawnia swoje emocje względem czegoś lub kogoś, łamiąc przy tym tabu językowe" [M. Grochowski, Stownik polskich przekleństw i wulgaryzmów, Warszawa 1995, s. 15]. O współczesnej sytuacji wulgaryzmów w sferze publicznej i kulturze zob. M. Kita, Estetyzowanie wulgaryzmów, „Stylistyka” 2016, nr XXV, s. 349-370.

43 Zob. A. Załazińska, O wulgaryzmach niewulgarnie, „Biuletyn Informacyjny Okręgowej Izby Radców Prawnych w Krakowie" 2020, nr 4, s. 40-43.
} 
„Rozróba w polszczyźnie” możliwa jest też dzięki emocjonalnemu ładunkowi, którym nasycona jest nie tylko sama leksyka gwarowa czy wulgaryzmy, ale też praktyki językowe bohaterów powieści. Uruchamiają ją akty słowne - zawstydzania, lżenia, pomstowania, poniżania, piętnowania, bluzgania, złorzeczenia, wyszydzania, ubliżania, wyklinania, przeklinania, wyśmiewania, samoponiżania. Wszystkie, zauważmy, operują w polu afektywnym. Aż tak intensywne nasycenie języka powieści ekspresywnymi gatunkami mowy ${ }^{44}$ i aktami deprecjacji odsłania reguły wiejskiego habitusu komunikacyjnego - od chłopackich przepychanek słownych:

- Ty ciubaryku jeden!

- Ty zgniła pyro!

- Ty chadziaju zabugorski!

- Ty marydolska wdówko!

- Ty Rusie jeden!

- Ty złodziejski smrodzie! [s. 138]

po krasomówczą zapalczywość matki, która niczym w Wielkiej Improwizacji rozwija swe tyrady przeciw Krajonkom:

Niby to gospodarz jest, ale jaki tam gospodarz! - chaziaj, co ma na nazwisko chaziajski, przysłowie jego: chalierapanie. Jemu, panie chalierapanie! Żadne tam pola, żadne role ani uprawy nie w głowie, on musi pilnować swego, on i przez dzień cały z piwnicy nie wyjdzie, on i nocować będzie tam przy kociołach i rurkach, bo tam są jego uprawy, bimbermajster z niego patentowany [s. 154].

Pilot zakotwicza więc afekty $w$ języku, otwierając powieść na mowę żywą w jej najbardziej ekspresywnych praktykach i gatunkach, gorących erupcjach słownych, pokazując ich sytuacyjne uwarunkowanie oraz działanie (lub nieskuteczność działania) w świecie międzyludzkim.

Równolegle $\mathrm{z}$ anarchizującym gestem "rozróby w polszczyźnie” Pilot proponuje jednak jeszcze inne działania - publikacja Słownika dawnej gwary Siedlikowa oraz wydana w 2021 książka Dzikie mięso ${ }^{45}$ wskazują bowiem na szerszy problem. Zwłaszcza ta ostatnia - Dzikie mięso - to cudowne pomnożenie polszczyzny, wielogłosowa babeliada, stworzona z setek cytatów po-

44 M. Bachtin, Problem gatunków mowy, w: tegoż, Estetyka twórczości stownej, przeł. D. Ulicka, Warszawa 1986.

45 M. Pilot, Dzikie mięso, Kraków 2021. Publikacja wydana w Linii eksperymentalnej wydawnictwa Korporacji Ha!art jest wznowieniem pod zmienionym tytułem i nazwiskiem książki Samodział, która ukazała się, jako dzieło Franciszka M. Pielotha, w 2003 roku. Siłą rzeczy nasuwa się pytanie, ile jeszcze takich mistyfikacji kryje twórczość Pilota. 
chodzących z ludowej, peryferyjnej mowy. Czasom wielkiego wymierania gwar, dialektów, języków lokalnych, regionalnych pisarz przeciwstawia swoiste „archiwum pamięci kultury" ${ }^{46}$, w którym znajduje miejsce dla słowotwórczej, inwencyjnej leksyki gwarowej i przekrętów słownych - orłoplanów i bałachwastów, siersoni, ciećwierzy i jendyków, angrysów i adukotów. Ale chyba przede wszystkim przekonanie o prawie do swojej polszczyzny: ,jak bałakam tak bałakam ale swojou czystou polskou mowou" ${ }^{47}$. „Rozróba” nie prowadzi więc do destrukcji polszczyzny, ale do jej rewitalizacji, a zarazem emancypacji wielogłosowej mowy wsi.

Językowy anarchizm i babeliada powieści oraz nawiązanie do tradycji sowizdrzalskiej ustanawiają zatem i rozgrywają to, o czym mówił Rakowski liminalność, transgresję i przekroczenie kultury zawstydzenia, choć w nader swawolny i wolnomyślicielski sposób. Transgresja nie polega oczywiście na wyjściu, ale na demontażu porządku dystynkcji ${ }^{48}$, kreatywnym, twórczym zderzaniu, przemieszaniu i wykolejaniu języków, pozaliterackich „peryferyjnych obszarów mowy" i wyrafinowanej literackiej polszczyzny. I wreszcie wstydu i bezwstydu, poruty i pychy, które w powieści błyskawicznie i bezustannie zamieniają się miejscami, raczej swobodnie dryfują $\mathrm{w}$ świecie międzyludzkim niż nieodwracalnie stygmatyzują. Najlepiej tę żywiołową i przewrotną aktywność ujął sam Pilot:

Chodziłem z głową $\mathrm{w}$ tęczowym obłoku polskich i siedlikowskich pawio pysznych i łachmaniarsko nędznych słów, radosny i szczęśliwy splatałem z nich pyszny barwisty pióropusz. Nie żądałem wiele, utulić się umiałem jednym słowem, nieledwie zgłoską, by kojarzyć ją, piękną z innymi zgłoskami i słowami - a potem ustanowione związki zrywać, wyłuskiwać głoski, wszeptywać inne dźwięki i brzmienia, przemieniać, przekształcać, a także zniekształcać, powodować kolizje, zgrzyty zgoła katastrofy i zagłady: wyjałowić słowo, wydrążyć je, pozbawić treści, wszelkiej zawartości, je zwariować, doprowadzić do bezsensu, obłędu lub też samozagłady, przeciwnie - uwznioślić..., o, nie były to czcze zabawy, daremne manewry, pustoty, to były fundamentalnej wagi operacje ratunkowe, oddechy i wytchnienia po ciężkich, wyczerpujących i brudzących czoło i palce robotach raport-szrajbera [s. 314-315].

Roch Sulima, zastanawiając się nad przeoczanymi lub tabuizowanymi współcześnie problemami kultury wsi, wskazał m.in. na jej ludyczność:

\footnotetext{
46 Zob. E. Sławkowa, Pióropusz Mariana Pilota: kolekcja stylów i archiwum pamięci kultury, s. 309.

47 M. Pilot, Dzikie mięso, s. 71.

48 Zwraca na to uwagę także K. Chmielewska, Wynalazek tożsamości, s. 220.
} 
Wciąż trwałym komponentem życia społecznego na wsi, niedocenianym przez badaczy, jest niemilknący żywioł ludowego śmiechu, widzianego jako działanie performatywne, metamorficzne, wciąż o istotnych funkcjach regulacyjnych $^{49}$.

Z tego punktu widzenia pisarstwo Pilota może patronować przekierunkowaniu i zmianie orientacji na perspektywę oddolną. Przypomina bowiem, że do kultury wsi należą również ludyczny, transgresyjny, sowizdrzalski żywioł językowy, „kielcowanie”, parodiowanie i przedrzeźnianie, o którym wspominał w innym jeszcze eseju Matecznika ${ }^{50}$. A przy okazji Pilot wydobywa jej aspekty i profanacyjne, i emancypacyjne, i rewitalizacyjne, w których język „nie jest dziełem (ergon), lecz działaniem (energeia)” ${ }^{51}$.

\section{Miastowieś}

Andrzej Muszyński w debiutanckim zbiorze opowiadań Miedza dopisuje kolejny rozdział do długiej historii „kresu” kultury wiejskiej, który tym razem odnosi się do realiów potransformacyjnych, a precyzyjniej, sytuacji wsi po wejściu do Unii Europejskiej. Ich najbardziej widocznym efektem w strukturze przestrzennej jest nowa forma osadnicza: "miastowieś" 52, ani wieś, ani miasto, hybryda reliktów starego i ekspansywnego nowego. I jeszcze jedna uwaga: począwszy od debiutu Muszyński lokalizuje wszystkie swoje narracje w różnych miejscach Jury Krakowsko-Częstochowskiej, okolic pustyni Błędowskiej, Olkusza i dolin podkrakowskich, a więc w przestrzeniach poddanych silnym procesom nowoosadniczym i dezagraryzacji.

Wśród dziewięciu opowiadań składających się na zbiór trzy mają formę monologu wypowiedzianego, a fragmenty stylizacji na narrację mówioną pojawiają się również $\mathrm{w}$ pozostałych. Wybór to symptomatyczny, z jednej strony monolog wypowiedziany jest kluczową tradycją, wręcz kanonem dla opowieści chłopskiej i prozy nurtu wiejskiego, stanowi pogłos oralnych, a nie piśmiennych źródeł kultury wsi. Z drugiej strony forma mo-

\footnotetext{
49 R. Sulima, Kultura wsi polskiej - co się wyłania? w: Ciagłość i zmiana. Sto lat rozwoju polskiej wsi, t. 3, red. M. Halamska, M. Stanny, J. Wilkin, Warszawa 2021, s. 138.

50 M. Pilot, Wielkie kielcowanie, w: Nowy matecznik, s. 203-220.

51 W. Humboldt, Rozmaitość języków a rozwój umysłowy ludzkości, przeł. E. Kowalska, Lublin 2002, s. 96.

52 A. Muszyński, Miedza, Wołowiec 2013, s. 20. Dalsze cytaty lokalizuję w tekście głównym.
} 
nologu wypowiedzianego umożliwia artykulację emocji ${ }^{53}-\mathrm{w}$ opowiadaniach manifestują się bowiem głosy gniewnych mężczyzn, patriarchalnych, dominujących, mocno ustawiających hierarchiczne relacje $\mathrm{z}$ młodszym interlokutorem i centralizujących własny punkt widzenia. Niemniej występują oni jednocześnie w roli „kronikarzy kultury śmierci” [s. 21] i wymierających wsi: „Dziś wszystko umarło. Zaczęli się wieszać” [s. 10]. Dzięki formie monologu wypowiedzianego Muszyński otwiera więc możliwość dania wyrazu wściekłości, frustracji, żalowi, wstydowi i gniewowi. Warto jeszcze zaznaczyć, że nie są to tylko emocje potransformacyjne, chłopski wstyd wyłania się jako założycielska reakcja na pierwsze sygnały nowoczesności, które w okolicach Olkusza pojawiły się wraz z kopalniami galmanu już w XVI wieku:

Robotnicy, gwarkowie. Od nich tu zaczął pękać świat. Te ich cajchorze i „auf Glück". Porzucili pola. Mieli pieniądze, wzięli nasze dziewki. Tak, młody, to zaczęło się już wtedy. „Wara, chłopie, wara, bo gwarek tańcuje. Wisi bat na ścianie, skórę ci zgarbuje". Przyszedł z nimi wstyd i upokorzenie. Czytali pierwsze gazety i nosili kitle. Podrostki o pszennych mordkach wyglądały zza drzew i też chciały być czarne. Ta, wisi bat na ścianie... [s. 15]

Wprawdzie Muszyński sięga w tym fragmencie do źródeł historyczno-etnograficznych, a dokładniej monografii Stanisława Ciszewskiego Lud rolniczo-górniczy z okolic Sławkowa w powiecie olkuskim ${ }^{54}$, wykorzystuje z niej jednak te elementy, z których wyłaniają się relacje nierówności. I pojawiające się wraz $\mathrm{z}$ nimi prymarne emocje - wstyd i upokorzenie. Włącza je zarazem w proces długiego trwania, w którym to, co nowe jest zawsze źródłem społecznego różnicowania, męskiej konkurencji („wzięli nasze dziewki”), a wraz z nimi poczucia poniżenia. Monologi są z tego punktu widzenia afektywnymi suplementami do historii społecznej, ekonomicznej, gospodarczej, modernizacyjnej regionu, przekładając ją na to, co jednostkowe i subiektywne, a w sferze publicznej słabo słyszalne.

Niemniej, po trzecie, monologi, zwłaszcza pierwszy, z opowiadania Bioły, zdradzają również konfliktowość umiejscowienia, tę synkretyczną dwoistość, która przekształca obecnie dawne wsie w miastowsie. Ujawniają zatem pozycję pomiędzy - są monologiem mieszkańca miastowsi, w którym dochodzi do interferencji dwóch rejestrów mowy. Widać to wyraźnie w języku

53 Zob. M. Głowiński, Narracja jako monolog wypowiedziany, w: tegoż, Narracje literackie i nieliterackie, Kraków 1997, s. 109.

54 S. Ciszewski, Lud rolniczo-górniczy z okolic Sławkowa w powiecie olkuskim, Kraków 1887. 
opowiadań - czasem szorstkim, kulawym, niepoprawnym z punktu widzenia normatywnej polszczyzny, ale czasem olśniewającym wyrafinowaną prostotą. Tym samym język zdradza, że wytwarzanie continuum „miejsko-wiejskiego" nie przebiega w sposób bezkolizyjny, to, co w wymiarze przestrzennym sprawia wrażenie niejako „samo-przez-się" działającego procesu zanikania starej wsi i tworzenia nowej, hybrydycznej formy osadniczej, tylko pozornie toczy się bezkonfliktowo. Za sprawą monologów Muszyński może odsłonić mechanizm afektywnej polaryzacji, antagonizacja nie dotyczy bowiem oddalonych od siebie przestrzeni miasta i wsi, antagonizacja przebiega wewnątrz, zostaje zinterioryzowana:

Mieszkam we wsi w szarym betonowym bloku. Od paru lat żyję na miedzy. Lubię przycupnąć i patrzeć, jak uważnie umiera świat. Potem wstaję i wracam nią wśród ugorów do domu. I tylko but mi się ślizga, raz w lewo, raz w prawo. Raz „ino", raz ,jedynie”, raz kwanty, raz gęsi. Pół litra czystej i Biblia Tysiąclecia. Czarny moleskine za pół stówy, a w nim spis zasianego [s. 20].

I jednocześnie wciąga w afektywną konfuzję czytelnika, jak w najbardziej zatrważającej scenie z opowiadania Bioły:

Szczyl od sąsiada naczytał się za dużo, aż go ojciec w pole wywiózł. Na jesień, gdy od południa biją ciężkie wichry. Stałem pod gruszą, widziałem. Kazał mu wsadzić nogi w wielki jutowy worek i przywiązał mu go powrozem do pasa. Drugi założył mu na głowę i zrobił to samo. Obrócił go twarzą do wiatru, pod śliską, lessową górę. I mówi, no to idź tera, zakalcu, i czytaj. Wiatr rąbnął o wiatr i rzucił chłopakiem o ziemię. Wstał. No idź i czytaj, ryczał stary. Młody wstał. Uszedł dwa kroki, poślizgnął się i upadł. Wstał. I ojciec na to: no idź tera, synu, i czytaj ciemność, pod wiatr. Młody upadł i wstał. Wiatr porwał go za worki i rąbnął na twarz [s. 20].

Nieco inaczej ten antagonizm zarysowuje Maciej Płaza - pierwszy rozdział powieści Skoruń przedstawia konflikt braci. I w tym przypadku antagonizacja jest efektem gestów słownych, stopniowego narastania gniewu ojca, "gospodarza-wścieklicy" 55 pod wpływem krytycznych uwag stryja, a kulminującego w „odwiecznym” zatargu „wsioka" i „miastowego", co ważne, rodzonych braci, obu rolników i sadowników:

- A widzisz, bo tyś jest wielki pan inżynier, a ja prosty wsiok. [...] Nie dlatego miastowy, że w mieście pracujesz, ale dlatego, żeś taki dumny, nie wiadomo nawet $\mathrm{z}$ czego. Głowę nosisz wysoko i ludzi nie szanujesz. [...] Wielki uczony inżynier. Też się nasłuchałem, jaki z ciebie nauczyciel.

55 M. Płaza, Skoruń, Warszawa 2015, s. 35. 
- No, jaki? - zaperza się ojciec, grzmoci pięścią w maszynę. - Jaki? Co ty mi wypominasz? Żem na studia poszedł? Uczyć się trzeba było, głąbie. Motor i panny miałeś w głowie. I wódę. Gdybyś się uczył, toby ci ojciec pieniądze na studia dał. Od ust by sobie odjął, a by dał. Wyżej sram, niż siedzę, kamieniecki wsioku? ${ }^{56}$

Płaza kapitalnie w tej scenie pokazał splot performatywnej siły słowa napędzającego afekty, ich cielesne symptomy, a zarazem trwałość społecznego obciążenia: bracia cytują przecież prymarny kod polskiego konfliktu. „Miastowy" i „wsiok" to słowa zapalniki, które błyskawicznie podgrzewają temperaturę każdej interakcji. Scena przenosi zarazem na poziom mikrorelacji rodzinnej i sytuacji codziennej kluczową dla sfery publicznej antagonizację ${ }^{57}$, choć równie uprawniona może być inna interpretacja - to w rodzinnych, prywatnych antagonizmach wzrasta i zagęszcza się źródło poczucia nierówności i polaryzacji. Zatarg nie zostaje rozładowany, tylko wygaszony ze względu na konieczność pracy.

I Muszyński, i Płaza aktywizują zatem „odwieczny” konflikt społeczny, przenosząc go jednak w sferę jednostkową, prywatną, rodzinną. A jednocześnie ujawniają afektywne zaplecze męskocentrycznego, twardego świata chłopskiego ${ }^{58}$, który w ich narracjach odsłania może nie tyle miękkie podbrzusze, ile wybuchowość i przeploty między przemocą, gniewem a upokorzeniem, żalem czy poczuciem winy (zwłaszcza Płaza). Pokazują tym samym patriarchalny świat wsi od środka, jego dziedziczoną męską przemoc (gwałt na Madzi odbywa się na błoniach, wcześniej „zgwałconych” przez ojca bohatera), oczywiście nie po to, by go usprawiedliwić, lecz skomplikować nazbyt oczywisty obraz.

\section{Sumieszki}

Proces przemieszczania języków peryferyjnych ze strefy prywatnej, domowej do przestrzeni publicznej przechodzi w ostatniej dekadzie wyraźne przyspieszenie. O ile wcześniej rozpoznawany był w kodzie alienacji, wywłaszczenia językowego (tak mocno artykułowanego przez Stefana Szymutkę w Nagrobku ciotki Cili), o tyle obecnie przybrał on postać prowadzonej na

\footnotetext{
56 Tamże, s. 25-26.

57 Zob. A. Woźniak, Co to znaczy być dzisiaj wieśniakiem? Antropologiczna analiza treści wypowiedzi internautów, "Journal of Urban Ethnology" 2020, nr 18.

58 O wiejskiej męskości zob. M. Gospodarczyk, Rolnicy, kowboje i drwale. Koncepcje wiejskich męskości w obszarze badań nad wsia, „Studia Socjologiczne” 2019, nr 4, s. 103-128.
} 
wielu polach kampanii o uznanie. Języki peryferyjne i dykcje lokalne mają swoich ambasadorów, pośredników i tłumaczy, co ważne, funkcjonujących zarówno w obiegach lokalnych, jak i centralnych. Jednym z nich jest Grażyna Kubica, która w autoetnograficznym szkicu Moja ślóńsko rzecz ${ }^{59}$ intencjonalnie wprowadza w przestrzeń publiczną prywatne doświadczenie językowe cieszyńskiej śląszczyzny i zarazem poddaje proces wypierania i powrotu do mowy domowej refleksji teoretycznej, podpowiadając jednocześnie słownik analizy problemu narzucania jednojęzyczności. Antropolożka zakłada, że takie operacje o podwójnym charakterze, doświadczeniowo-refleksyjnym oraz przekraczającym granice między prywatnym a publicznym, są jednym z czynników wspierających proces emancypacji językowej i podnoszenia prestiżu mowy śląskiej.

Ważnym aktem było również wystąpienie Szczepana Twardocha podczas wręczania mu tytułu Ambasadora Polszczyzny przyznanego w 2019 roku. Pisarz - jako świeżo nominowany Ambasador Polszczyzny - zwrócił uwagę nominującej go Radzie Języka Polskiego (przeciwnej uznaniu śląskiego za język regionalny), że „dystynkcja między językiem a dialektem jest dystynkcją polityczną, nie zaś naukową [...]. Dziś nikt nie kwestionuje już statusu języka kaszubskiego jako języka regionalnego, podczas kiedy jeszcze trzydzieści lat temu bardzo wielu polskich - i wyłącznie polskich - językoznawców życzyło sobie widzieć ten język jako zaledwie polszczyzny dialekt" 60 .

Co warto jeszcze podkreślić, proces oddolnego upominania się o mniejsze języki, funkcjonujące $\mathrm{w}$ peryferyjnych lokalizacjach i równolegle wobec języka narodowego, nie jest tylko polską specyfiką - to ruch o zasięgu światowym, a w Europie aktywny od lat sześćdziesiątych ${ }^{61}$. We Włoszech na przykład, po okresie dominacji standardowego języka włoskiego, mówi się wręcz o nowym życiu dialektów; jak zauważa Julia Murrmann:

Obserwuje się liczne nowe fenomeny związane z dialektami lokalnymi, takie jak: zafascynowanie dialektami i wynikająca z niego wzmożona obecność spuścizny dialektalnej w produktach kultury popularnej i masowej (w muzyce

59 G. Kubica, Moja ślóńsko rzecz. Szkic autoetnograficzny, „Socjolingwistyka” 2019, nr 32, s. 39-59. Zob. też E. Michna, Emancypacja śląszczyzny w kontekście "starych" $i$ "nowych" ideologii jezzykowych. „Postscriptum Polonistyczne” 2019, nr 1, s. 57-76.

${ }^{60}$ https://www.facebook.com/photo.php?fbid=10216625942662647\&set=a.1201502239349\& type $=3$ [dostęp 30.11.2021].

61 N. Dołowy, Możliwości rewitalizacji zagrożonych języków: między odpowiedzialnościa państwa a działaniami mniejszości językowych, „Kultura i Społeczeństwo” 2008, nr 2, s. 214. Zob. też N. Dołowy-Rybińska, "Nikt za nas tego nie zrobi”. Praktyki językowe i kulturowe młodych aktywistów mniejszości językowych, Torun 2017. 
młodzieżowej, w filmie, w literaturze pięknej, w reklamie, na blogach), proces konwergencji pomiędzy tymi dwoma kodami, czyli italianizacja dialektów i dialektyzacja włoskiego, uwolnienie dialektów spod jarzma stygmatyzacji społecznej, marginalizacji społecznej czy wręcz wykluczenia społecznego, pozbawienie go „etykietki" kodu klas niższych oraz związana z tym zmiana wizerunku dialektu i postrzegania go jako elementu wzbogacającego repertuar językowy jednostki, a nie synonimu prostactwa i nieuctwa czy przejaw zacofania ${ }^{62}$.

Dostrzegalne jest zatem przesunięcie nie tylko społeczne, klasowe, związane $\mathrm{z}$ prestiżem, ale też emocjonalne. Interesujące są w tym przypadku wyniki badań świadomości językowej młodych Włochów - dla nich dialekty (postrzegane często jako języki regionalne: neapolitański, sardyński, sycylijski) to języki gościnności, solidarności, przywiązania, nośniki emocji, które są w ich przekonaniu bliżej opisywanej rzeczywistości, mają mocniejszy ładunek ekspresywny, ludyczny i większą zdolność artykulacji silnych afektów ${ }^{63}$. Zmienia się afektywna aura otaczająca peryferyjne obszary mowy, nie wiąże się z nimi już tylko wstyd, ale coraz częściej przekorna duma.

Otwarcie na języki peryferyjne w literaturze ostatniej dekady wymaga, jak zauważa Ewa Sławkowa, rewizji oraz innego opisu niż tradycyjne rozpoznania stylizacji gwarowej ${ }^{64}$. Klasyczne już prace analizujące dialektyzację w literaturze ${ }^{65}$ koncentrowały się bowiem na funkcjach wewnątrzliterackich, badaczka w miejsce dawnych kategorii proponuje natomiast „słowo gwarowe":

Słowo gwarowe nie jest więc dla mnie na pewno równoznaczne z systemem konkretnej gwary, w większym lub mniejszym stopniu odtwarzanym na kartach utworów i służącym wyłącznie stworzeniu kolorytu lokalnego, charakterystyki środowiska czy języka postaci. Bliskie jest natomiast słowu Innego/Obcego. Może być więc głosem kogoś gorszego, często potencjalnie wykluczonego, kto znajduje się lub znajdować powinien pozą przestrzenią należącą do Swojego ${ }^{66}$.

62 J. Murrmann, Miejsce i rola dialektu w repertuarze językowym młodego pokolenia Włochów. Diagnoza socjolingwistyczna, „Socjolingwistyka” 2016, nr 30, s. 25.

63 Tamże, s. 30-35.

64 E. Sławkowa, Miejsce słowa gwarowego w literaturze polskiej ostatnich dziesięcioleci, „Poradnik Językowy" 2019, nr 7, s. 84. O różnych wariantach wykorzystania gwary w literaturze współczesnej por. też: B. Wyderka, O stylizacji gwarowej dyskusyjnie (na materiale wybranych utworów wspótczesnej prozy polskiej), „Rozprawy Komisji Językowej ŁTN” 2017, t. 64, s. 333-351.

65 S. Dubisz, Stylizacja gwarowa w polskiej prozie trzydziestolecia powojennego (nurt ludowy w latach 1945-1975), Wrocław 1986; S. Dubisz, Stylizacja gwarowa w historii polskiego jezzyka artystycznego, „Prace Filologiczne” 2016, nr 69, s. 115-128.

66 E. Sławkowa, Miejsce słowa gwarowego w literaturze polskiej ostatnich dziesięcioleci, „Poradnik Językowy" 2019, nr 7, s. 88. 
Tak rozumiane słowo gwarowe może obejmować różne elementy od pojedynczych leksemów po rozbudowane, wieloskładnikowe segmenty, które jednak prowadzą do znaczeń związanych z brakiem uznania lub marginalizacją danego języka ${ }^{67}$. Jakkolwiek warto dopowiedzieć, że nie są to jedyne możliwości. Jednym z przywoływanych przez badaczkę przykładów jest Sońka Karpowicza i jej innojęzyczność. Katarzyna Sawicka-Mierzyńska wskazała, że wartość języka pa prostu w tym przypadku wiąże się z jego indyferencją ideologiczną:

jest to świat, w którym język „po prostu” określa rzeczywistość, zwyczajnie do niej przystaje i o niej orzeka. Bez nieustających, znoszących się nawiasów i cytatów, bez symulakrów i ironii (będą domeną "Warszawy"), hermetyczny i naiwny, przez to bezpieczny, a zarazem bezbronny wobec różnych, świadomych siebie dyskursów - czy to będzie dyskurs narodowy, czy artystyczny. Język, który bez przekładu - co pokazuje Karpowicz w Sońce - nie ma szans na komunikację ze współczesnym, ponowoczesnym światem ${ }^{68}$.

Renata Makarska proponuje natomiast do opisu tego typu zjawisk "tekstową wielojęzyczność”, która jest „wyrazem protestu wobec jednojęzycznej kultury oficjalnej (również wobec automatyzmu języka)", a także sposobem zapisywania miejsca ${ }^{69}$. Karolina Pospiszil taki rodzaj rozwiązań językowych nazywa z kolei literaturą przepływów, przy czym „przepływowość” oznacza "nie tylko zmiany kodów językowych, ale także świadomość idących za wyborem języka (samo)określeń, co dotyczy nie tylko warstwy literackiej utworów, ale i tego, jak działają one w przestrzeni publicznej"70. Podkreśla także, że kluczową kwestią jest $\mathrm{w}$ tym przypadku przekroczenie wieloletniej kultury zawstydzenia (wdrażanej przez system edukacyjny) oraz przejście dzięki wehikularnej mocy literatury - z języka wernakularnego, domowego do języka publicznego, a tym samym przeciwdziałanie marginalizowaniu określonych wspólnot językowych:

Mamy tu bowiem do czynienia z nierównorzędnym statusem obu kodów - wszelkie przejawy regionalnej (wy)mowy okazują się cechą stygmatyzującą, dopuszczalną jednak - jak pokazują badania, dopóki nie wychodzi się poza

\footnotetext{
67 Tamże, s. 87.
}

68 K. Sawicka-Mierzyńska, Poruszyć miejsce. Obraz Białegostoku w twórczości Sokrata Janowicza i Ignacego Karpowicza, Białystok 2018, s. 214.

69 R. Makarska, Tekstowa wielojęzyczność jako zapisywanie miejsca. Regionalizm, polikulturowość i wielojęzyczność nowej literatury z Europy Środkowej, „Wielogłos” 2016, nr 2, s. 81-98.

70 K. Pospiszil, Literatura przeptywów? Kilka uwag o literaturach etnolektalnych, „Anthropos” 2018, nr 27, s. 141. 
użytek domowy („kuchenny”). A ruchem na zewnątrz tej przestrzeni jest działalność artystyczna, w tym literacka. Użycie mowy domowej poza "typowym" kontekstem ma ogromne znaczenie dla tożsamości regionalnej oraz budowania/wzmacniana lokalnej wspólnoty. Z jednej strony wpisuje się $\mathrm{w}$ „walkę o uznanie", "odzyskiwanie głosu” czy przeciwdziałanie minoryzacji niektórych wspólnot regionalnych/kulturowych, jak Kaszubów czy Górnoślązaków, ma więc charakter $\mathrm{w}$ jakimś stopniu subwersywny, z drugiej stanowi część „walki ze wstydem”, podnoszenia prestiżu regionalnego etnolektu, pokazania jego wielofunkcyjności (niekoniecznie w opozycji do języka dominującego); może być też elementem rewitalizacji kultury lokalnej, jej ochrony przed wymarciem, co ma miejsce np. w przypadku wilamowskim ${ }^{71}$.

Zarówno rozpoznania językoznawcze, jak i literaturoznawcze wskazują więc wyraźnie na zmianę funkcji wykorzystania peryferyjnych obszarów mowy w literaturze współczesnej.

Literatura peryferii, tak jak peryferyjny $\mathrm{w}$ swoim czasie Adam Mickiewicz, pokazuje język ${ }^{72}$, język jako sumieszkę. Sięgając po to gwarowe słowo, Stanisław Pigoń upominał się w recenzji pierwszych tomów Słownika języka Adama Mickiewicza o uwzględnienie regionalizmów poety:

poeta [...] przez całe swoje życie nie był ani razu, ani na chwilę w Warszawie, cóż mówić o Krakowie! Wyrósł w Nowogródku, a polszczyzną władał taką, jaką wyrobił sobie w domu rodzinnym, w szkole nowogródzkiej, w uniwersytecie wileńskim i wśród kolegów uniwersyteckich, prawie wszystkich "tutejszych". Czyż ma dziwić, że polszczyzna jego tak silnie jest nasycona regionalizmami? Że tak zmieszane są $\mathrm{w}$ niej elementy ogólnopolskie $\mathrm{z}$ miejscowymi, gwarowymi? Taką to sumieszką poeta wzbogacał (były zdania, że zaśmiecał) nasz język literacki ${ }^{73}$.

Sumieszka, jak sugeruje Danuta Ulicka, może być bardziej adekwatnym w przypadku literatury polskiej ekwiwalentem hybrydyzacji ${ }^{74}$ i wydaje się

71 Tamże.

72 Nawiązuję oczywiście do pomysłu Przemysława Czaplińskiego. Zob. P. Czapliński, Polityka literatury, czyli pokazywanie języka, w: Polityka literatury. Przewodnik Krytyki Politycznej, red. K. Dunin, Warszawa 2009, s. 38.

73 S. Pigoń, Na marginesie "Stownika” Mickiewiczowskiego, w: tegoż, Drzewiej i wczoraj. Wśród zagadnień kultury i literatury, Kraków 1966, s. 191. O regionalizmie językowym Mickiewicza zob. m.in.: Z. Kurzowa, O języku Adama Mickiewicza, „Język Polski” 1998, nr 5, s. 290-302. Zob. też przeglądowy artykuł M. Szpiczakowska, Język Adama Mickiewicza w świetle dotychczasowych badań - ustalenia i postulaty, w: Badania historycznojęzykowe. Stan, metodologia, perspektywy, red. B. Dunaj, M. Rak, Kraków 2011.

74 D. Ulicka, Rzut oka na nowoczesne polskie literaturoznawstwo teoretyczne, w: Wiek teorii. Sto lat nowoczesnego literaturoznawstwa polskiego, red. D. Ulicka, Warszawa 2020, s. 113. 
też lepiej zestrojona z procesami przenikania peryferyjnych obszarów mowy do języka literackiego. Nie jest to oczywiście problem nowy, a sama historia i kwestia porównania kolejnych fal otwierania na sumieszki byłaby warta bardziej szczegółowego rozważenia. Wracając jednak do prozy ostatniej dekady, powtórzę: literatura peryferii pokazuje język, by zademonstrować niezbywalną różnojęzyczność polskiej mowy i aby, dzięki swej wehikularnej mocy, demontować porządek dystynkcji, czerpiąc przekorną siłę, dumę, inwencję $\mathrm{z}$ tego, co zawstydzane.

\section{Bibliografia}

Bachtin Michaił (1986), Problem gatunków mowy, w: M. Bachtin, Estetyka twórczości słownej, przeł. D. Ulicka, Warszawa: PIW, s. 348-357.

Banaś-Korniak Teresa (2007), Ambiwalencja znaczeń: o językowych eksperymentach sowizdrzałów, w: T. Banaś-Korniak, Pomiędzy tragicznościa a groteska. Studium z literatury $i$ kultury polskiej schytku renesansu i wstępnej fazy baroku, Katowice: Wydawnictwo Uniwersytetu Śląskiego, s. 210-221.

Bereza Henryk (1978), Związi naturalne. Szkice literackie, Warszawa: Ludowa Spółdzielnia Wydawnicza.

Chmielewska Katarzyna (2013), Wynalazek tożsamości, w: Gry o tożsamość w czasach wielkiej zmiany, red. A. Werner, T. Żukowski, Warszawa: Wydawnictwo IBL PAN, s. $198-223$.

Ciszewski Stanisław (1887), Lud rolniczo-górniczy z okolic Sławkowa w powiecie olkuskim, Kraków: Drukarnia Uniwersytetu Jagiellońskiego.

Czapliński Przemysław (2009), Polityka literatury, czyli pokazywanie języka, w: Polityka literatury. Przewodnik Krytyki Politycznej, red. K. Dunin, Warszawa: Wydawnictwo Krytyki Politycznej, s. 6-22.

Czapliński Przemysław (2017), Śmierć, śmierć, inne życie. Wieś w literaturze polskiej, "Teksty Drugie”, nr 6, s. 13-34.

Czyżak Agnieszka (2019), Mutacje gatunkowe czy przekroczenie konwencji - wokół zagadnień prozy wiejskich przestrzeni, „Zagadnienia Rodzajów Literackich”, nr 3, s. 53-64.

Dołowy Nicole (2008), Możliwości rewitalizacji zagrożonych języków: między odpowiedzialnościa państwa a działaniami mniejszości językowych, „Kultura i Społeczeństwo”, nr 2, s. 209-228.

Dołowy-Rybińska Nicole (2017), „Nikt za nas tego nie zrobi”. Praktyki językowe i kulturowe młodych aktywistów mniejszości językowych, Torun: Wydawnictwo Naukowe Uniwersytetu Mikołaja Kopernika.

Dubisz Stanisław (1986), Stylizacja gwarowa w polskiej prozie trzydziestolecia powojennego (nurt ludowy w latach 1945-1975), Wrocław: Zakład Narodowy im. Ossolińskich Wydawnictwo PAN. 
Dubisz Stanisław (2016), Stylizacja gwarowa w historii polskiego języka artystycznego, „Prace Filologiczne”, nr 69, s. 115-128.

Dziewit-Meller Anna (2020), Od jednego Lucypera, Kraków: Wydawnictwo Literackie. Franczak Jerzy (2019), Śmierć kultury chłopskiej. Scenariusze żałobne Edwarda Redlińskiego, w: J. Franczak, Maszyna do myślenia. Studia o nowoczesnej literaturze i filozofii, Kraków: Universitas, s. 125-142.

Gajda Stanisław (2015), Gwara a język literacki, w: Amor verborum nos unit. Studia poświęcone pamięci Profesora Sławomira Gali, red. P. Stalmaszczyk, I. Jaros, Łódź: Wydawnictwo Uniwersytetu Łódzkiego, s. 79-88.

Głowiński Michał (1997), Narracja jako monolog wypowiedziany, w: M. Głowiński, Narracje literackie $i$ nieliterackie, Kraków: Universitas, s. 85-113.

Gombrowicz Witold (1988), Trans-Atlantyk, Kraków: Wydawnictwo Literackie.

Gospodarczyk Marta (2019), Rolnicy, kowboje i drwale. Koncepcje wiejskich męskości w obszarze badań nad wsia, "Studia Socjologiczne", nr 4, s. 103-128. DOI: $10.24425 /$ sts.2019.126158

Gospodarczyk Marta, Kożuchowski Łukasz (2021), Nowa ludowa historia: charakterystyka i społeczno-polityczne korzenie współczesnych narracji o historii chłopów polskich, „Studia Socjologiczne”, nr 2, s. 177-198.

Grochalska Monika (2011), Transgresyjne trajektorie. Zmiana statusu społecznego w perspektywie biograficznej, Kraków: Oficyna Impuls.

Grochowski Maciej (1995), Słownik polskich przekleństw i wulgaryzmów, Warszawa: Wydawnictwo PWN.

Grzeszczuk Stanisław (1994), Błazeńskie zwierciadło. Rzecz o humorystyce sowizdrzalskiej XVI i XVII wieku, Kraków: Universitas.

Humboldt Wilhelm (2002), Rozmaitość języków a rozwój umysłowy ludzkości, przeł. E. Kowalska, Lublin: Wydawnictwo KUL.

Kita Małgorzata (2016), Estetyzowanie wulgaryzmów, „Stylistyka”, nr 25, s. 349-370.

Kubica Grażyna (2018), Moja ślóńsko rzecz. Szkic autoetnograficzny, „Socjolingwistyka”, nr 32, s. 39-59.

Kurzowa Zofia (1998), O języku Adama Mickiewicza, „Język Polski”, nr 5, s. 290-302.

Makarska Renata (2016), Tekstowa wielojęzyczność jako zapisywanie miejsca. Regionalizm, polikulturowość i wielojęzyczność nowej literatury z Europy Środkowej, „Wielogłos” nr 2, s. 81-98.

Marecki Piotr (2011), „Nam wieczna w polszczyźnie rozróba”. Marian Pankowski mówi, Kraków: Korporacja Ha!art.

Michna Ewa (2019), Emancypacja ślasszczyzny w kontekście "starych" i "nowych" ideologii językowych. „Postscriptum Polonistyczne”, nr 1, s. 57-76. DOI: 10.31261/PS_P. 2019.23.05

Murrmann Julia (2016), Miejsce i rola dialektu w repertuarze językowym młodego pokolenia Włochów. Diagnoza socjolingwistyczna, „Socjolingwistyka”, t. 30, s. 23-37.

Muszyński Andrzej (2013), Miedza, Wołowiec: Wydawnictwo Czarne.

Myśliwski Wiesław (2003), Kres kultury chłopskiej, Warszawa: Prowincjonalna Oficyna Wydawnicza.

Obracht-Prondzyński Cezary (2020), Ludowa historia Polski - ksią̇ka ważna i zasługująca na krytyczna lekture, „Kultura i Społeczeństwo”, nr 4, s. 207-216. 
Pigoń Stanisław (1966), Na marginesie „Słownika” Mickiewiczowskiego, w: S. Pigoń, Drzewiej i wczoraj. Wśród zagadnień kultury i literatury, Kraków: Wydawnictwo Literackie, s. 184-192.

Pigoń Stanisław (1983), Z Komborni w świat. Wspomnienia młodości, Warszawa: Ludowa Spółdzielnia Wydawnicza.

Pieloth M. Franciszek (2003), Samodział, Warszawa: Agencja KUBA.

Pilot Marian (2010), Pióropusz, Kraków: Wydawnictwo Literackie.

Pilot Marian (2011), Ssapy, szkudły, świętojanki. Słownik dawnej gwary Siedlikowa, Warszawa: Agencja KUBA.

Pilot Marian (2012), Nowy matecznik, Kraków: Wydawnictwo Literackie.

Pilot Marian (2021), Dzikie mięso, Kraków: Korporacja Ha!art.

Pilot Marian, Koźbiel Janina (2012), Zbici z pantałyku, „Więź”, nr 5-6, s. 127-138.

Płaza Maciej (2015), Skoruń, Warszawa: Wydawnictwo WAB.

Pospiszil Karolina (2018), Literatura przepływów? Kilka uwag o literaturach etnolektalnych, „Anthropos", nr 27, s. 137-150.

Rakowski Tomasz (2016), Sztuka w przestrzeniach wiejskich i eksperymenty etnograficzne. Pożegnanie kultury zawstydzenia: jednoczasowość, zwrot ku sobie, proto-socjologia, „Teksty Drugie”, nr 4, s. 66-87. DOI: 10.18318/td.2016.4.4

Rewers Ewa (1994), Wartościowanie peryferyjnych obszarów mowy w "Czarnej poezji" Andrzeja Bursy, „Pamiętnik Literacki”, nr 2, s. 136-149.

Ryś Paweł Wiktor (2015), Zwrot plebejski we współczesnej polskiej humanistyce i debacie publicznej, w: Historia. Interpretacja. Reprezentacja, t. 3, red. L. Mokrzecki, M. Brodnicki, J. Taraszkiewicz, Gdańsk: Wydawnictwo Athenae Gedanenses, s. 307-317.

Sabała Martyna (2012), Wymoczek vs. Niczciwiara. Pejoratywne określenia człowieka w Pióropuszu Mariana Pilota, „StruNa - Biuletyn Młodych Naukowców”, nr 1, s. 88-95.

Sagan-Bielawa Mirosława (2014), Dziedzictwo pozaborowe: społeczna świadomość językowa Polaków w Drugiej Rzeczypospolitej, Kraków: Księgarnia Akademicka.

Sagan-Bielawa Mirosława (2017), Język jako element świadomości społecznej (na przykładzie Polski po 1918 roku), „LingVaria”, nr 2, s. 211-224.

Sawicka-Mierzyńska Katarzyna (2018), Poruszyć miejsce. Obraz Białegostoku w twórczości Sokrata Janowicza i Ignacego Karpowicza, Białystok: Wydawnictwo Prymat.

Skrendo Andrzej (2017), "Nocny złodziej jabłek” - Henryk Bereza i nurt chłopski w prozie polskiej, „Teksty Drugie”, nr 6, s. 36-53.

Sławkowa Ewa (2013), Pióropusz Mariana Pilota: kolekcja stylów i archiwum pamięci kultury, "Stylistyka”, t. 22, s. 309-324.

Sławkowa Ewa (2019), Miejsce słowa gwarowego w literaturze polskiej ostatnich dziesięcioleci, „Poradnik Językowy”, nr 7, s. 84-94.

Sulima Roch (2021), Kultura wsi polskiej - co się wyłania? w: Ciagłość i zmiana. Sto lat rozwoju polskiej wsi, t. 3, red. M. Halamska, M. Stanny, J. Wilkin, Warszawa: IRWIR PAN, Wydawnictwo Naukowe Scholar.

Szpiczakowska Monika (2011), Język Adama Mickiewicza w świetle dotychczasowych badań - ustalenia i postulaty, w: Badania historycznojęzykowe. Stan, metodologia, perspektywy, red. B. Dunaj, M. Rak, Kraków: Księgarnia Akademicka, s. 53-64. 
Ulicka Danuta (2020), Rzut oka na nowoczesne polskie literaturoznawstwo teoretyczne, $\mathrm{w}$ : Wiek teorii. Sto lat nowoczesnego literaturoznawstwa polskiego, red. D. Ulicka, Warszawa: Wydawnictwo IBL, s. 9-159.

Woźniak Anna (2020), Co to znaczy być dzisiaj wieśniakiem? Antropologiczna analiza treści wypowiedzi internautów, ,Journal of Urban Ethnology", nr 18, s. 239-266.

Woźniak Ewa (2015), Polityka językowa państwa polskiego w okresie międzywojennym, "Socjolingwistyka", nr 29, s. 7-20.

Wyderka Bogusław (2017), O stylizacji gwarowej dyskusyjnie (na materiale wybranych utworów wspótczesnej prozy polskiej), „Rozprawy Komisji Językowej ŁTN”, t. 64, s. 333-351.

Załazińska Aneta (2020), O wulgaryzmach niewulgarnie, „Biuletyn Informacyjny Okręgowej Izby Radców Prawnych w Krakowie", nr 4, s. 40-43.

\title{
Peripheries Show Language: \\ On Geolinguistic Aspects of Prose of the Last Decade
}

\begin{abstract}
The aim of the article is to describe the relationship between rural space, emotions and language in the Polish prose between 2010 and 2021. The starting point is the question about what scenarios for crossing the culture of shame are proposed by the literature of peripheral spaces. The article concentrates on the language analysis of the novel and the functions of the gwara (patois), regional dialects, profanity and expressive speech genres. In this way, it draws attention to the flows from the vernacular, home language to the public language, and thus counteracts the marginalization of specific linguistic communities. Literature and its language are treated as a tool for dismantling social distinctions.
\end{abstract}

Keywords: Polish literature 2010-2021, space, periphery, language, emotions 